
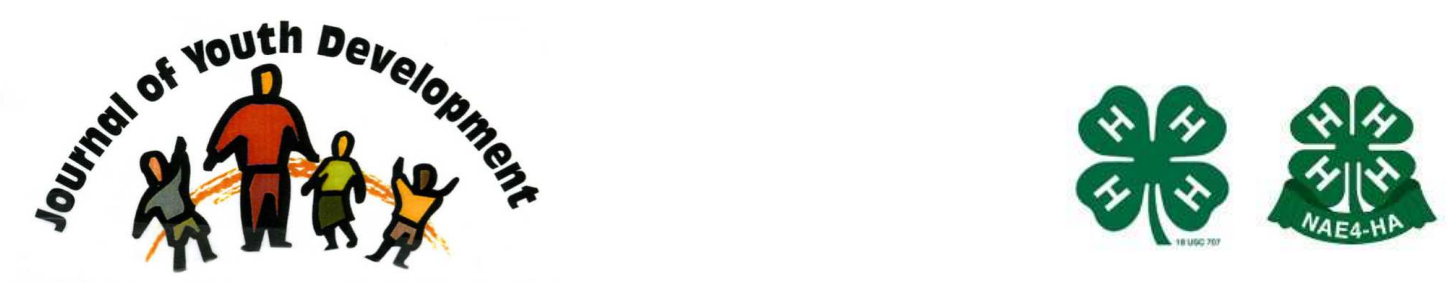

Bridging Research \& Practice

\title{
Tooele County 4-H Youth Garden: An Interactive Approach
}

\author{
Stephen Sagers \\ Utah State University Extension \\ Tooele County 4-H \\ Tooele, UT \\ stephen.sagers@usu.edu \\ Linden Greenhalgh \\ Utah State University Extension \\ Tooele County 4-H \\ Tooele, UT \\ linden.greenhalgh@usu.edu \\ Darlene Christensen \\ Utah State University Extension \\ Tooele County 4-H \\ Tooele, UT \\ darlene.christensen@usu.edu
}

Terra Sherwood

Tooele City Youth Services

Tooele, UT

terras@TooeleCity.org 


\title{
JOURNAL OF YOUTH DEVELOPMENT \\ bridging research and practice

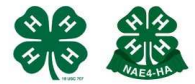

Bridging Research \& Practice

Volume 6, Number 4, Winter 2011

Article 110604PA003

\section{Tooele County 4-H Youth Garden: An Interactive Approach}

Stephen Sagers, Linden Greenhalgh, Darlene Christensen and Terra Sherwood

\begin{abstract}
The Tooele City 4-H Youth Garden program was designed to provide a non-traditional recreational activity for a growing youth population. Children ages $5-18$, assisted by parents and other family members, tend an $8^{\prime} x 15^{\prime}$ garden plot. A small registration fee covers 4-H enrollment. Tooele City provides land, water, employees, maintenance and equipment. Participants provide their own seed and labor, must attend an orientation in the spring, commit to work at least once each week in the garden, and attend periodic club meetings during the growing season. Club meetings cover basic gardening principles and specific issues related to individual garden plots. Approximately 800 youth have been involved since it was first organized in 2002. Many members have "graduated" or gone on to having their own gardens. The youth garden project has been a success due to a combination of dedicated leadership, hands-on learning and tangible, edible results.
\end{abstract}

\section{Introduction}

Multiple studies have shown positive impacts on youth when involved with gardening (Lohr \& Pearson-Mims, 2005; Pothukuchi, 2004). Involving youth in gardening encourages positive attitudes toward nature and the environment (Lohr \& Pearson-Mims, 2005). This paper documents the benefits to participants of the Tooele City 4-H Garden, highlights the effectiveness of community collaboration, and provides information for others to implement a similar program. Program replication details are also provided.

\section{Purpose}

Tooele City 4-H Youth Garden Club was created in 2000. Tooele City had multiple programs providing traditional activities such as dance and sports, but the new director of the parks and recreation was asked to come up with ideas to reach a broader audience. Over $36 \%$ of the population in Tooele County is 19 years and younger (Tooele County Profile, 2009). The Tooele 
City Youth Garden was created to offer non-traditional programming to families and youth and reach more of these youth.

The Garden Club's popularity increased after an interagency partnership was formed, and new curriculum was integrated into the program. Utah State University Extension and Tooele City Parks and Recreation combined resources to develop a successful program, which has benefited hundreds of youth throughout Tooele County.

\section{Program Objectives}

In organizing the Tooele City 4-H Garden Club, the following program objectives were developed:

- Provide non-traditional programs that would meet the needs of a universal population.

- Offer a hands-on, interactive approach to learning new skills that can be applied elsewhere.

- Build family and relationships skills through working together.

- Improve work ethics and empower youth to take responsibility for success.

- Make available an affordable program to families, regardless of socio-economic status.

- Present enjoyable activities that will empower youth and families through accomplishment.

\section{Program Guidelines}

- A registration fee of $\$ 7$ covers $4-\mathrm{H}$ enrollment, maintenance, and other expenses.

- Tooele City provides water, land, employees, maintenance, and equipment. Due to an approximate 20 hours per week time commitment paid employees are necessary.

- The employees conduct meetings that allow the club to have 3 different meeting times per week. They also ensure that the irrigation works properly, assign plots to families, coordinate soil preparation, find volunteers for special projects, and perform other administrative tasks.

- An approximate $8^{\prime} \times 15^{\prime}$ parcel is provided to each participant.

- Youth and parents commit to work once per week or risk losing the plot.

- Club members generally provide their own seed and equipment.

- New members must attend an orientation in the spring.

- Club meetings are held at three different times to accommodate various schedules. During the club meetings lessons such as those from the Jr. Master Gardener are taught. Youth also meet to have activities, complete leadership responsibilities, and reunite with other friends involved in the project.

\section{Teaching Methods}

Research has consistently concluded that learning opportunities which provide a chance to "do" or experience, result in a higher level learning environment and greater retention of knowledge (Richardson, 1994). Experiential learning teaching techniques have proven successful with the Tooele City 4-H Garden Club participants. The 4-H slogan "learn by doing" is truly embraced. 
Comprehensive education includes not only general gardening techniques, but also nutrition, recycling, entomology, environmental education and soil science. Each youth participant receives their own workbook, which correlates with weekly topics. Posters and visual aids are shown to enhance teaching methods. Activities and educational games are used to engage youth and foster an enjoyable educational environment. The Junior Master Gardener program is used as the core curriculum and is supplemented with additional staff-generated ideas that have shown to be successful.

In order to recruit and retain youth, incentives have been put into place. Each individual member is given complete control of the small parcel of land with the agreement that they tend it for the summer. This has been much more successful than trying to have the group work a common space of land. Ownership and responsibility are essential elements to provide youth motivation to finish their project. The youth are encouraged to decorate their area with crafts they create during club meetings such as painted rocks, signs, and other decorative items. This "ownership" gives youth a greater incentive to care for their garden patch. With this arrangement the vast majority of youth work throughout the summer because they feel a vested interest in the program. There are no free-riders in the garden club; instead all of the youth take great pride in their plot. Additional incentives are provided to keep the youth's interest in growing their gardens such as points, parties, and other fun activities.

\section{Impacts}

The Tooele City 4-H Garden Club has grown from a simple concept to a far reaching program that serves approximately 120 youth and their families each year. During the first year there were less than 15 youth involved in the program and goals and objectives were not established. Tooele City requested help from the USU Extension Office in Tooele County who provided curriculum, logistical expertise, and the concept of a 4-H Club to enhance the program. The program grew dramatically after the interagency partnership was formed and extension ideas were implemented. The past several years a waiting list has formed due to the fact that so many youth cannot be accommodated.

Due to the enrollment growth, the setting is more conducive to positive social interaction and youth encourage one another. An example of a positive interaction is how participants have dealt with vandalism. When plants or garden produce was ruined due to malicious acts, other participants have offered have offered their own fruits and vegetables to the kids that were victims of this damage. These lessons have helped youth learn much more than how to grow plants.

After detailing the success and growth of the project, Tooele City has provided additional funding for the program. With the additional money, more employees were hired as assistants to expand and enhance the program.

Participant comments include:

Youth comments:

- "I learned to be patient and let me plants grow, and I had fun, my pumpkins are almost done."

- $\quad$ "I like garden club because it is fun, gives me something to do in the evening. We have been here for 5 years. It's just inspiring for us. You should join."

- "I like garden club because you can eat your plants." 
- "I really like garden club because it gives us food and it teaches us. It's so fun the teachers are so nice. I love it."

- "I like weeding my garden."

Parent comments:

- "Garden club gave my daughter a good experience in being responsible and she also learned how to make zucchini bread! [My daughter] looked forward to what was going to be there every week. The activities were also very fun."

- "The club is a great way to bring the community together. It provides a very positive environment."

- "Garden club teaches kids that hard work pays off (and that it tastes good)!'

- "I am happy my son was in garden club, it taught him ne skills and responsibility and he had fun!"

- "The garden club has made me prepare one [garden] at home."

\section{Implementation}

In order to implement such a program a partnership with another entity is essential. There is an increased demand for fresh produce and urban gardening. Extension is in a position to tap into that market with the proper partnerships. Since most Extension Offices do not have all of the resources and real estate to begin such a program, an organization that has access to land and equipment will be needed to form a partnership. Generally a public entity such as a city or county that has access to available space and equipment is a viable partner. Running such a program can be a time consuming operation, so an interagency partnership will usually ensure a greater quality program. A paid employee can provide the necessary attention to this type of project and can make such a program successful. The keys to successfully implementing this program require three main components.

- The ability of the extension office and an outside agency to establish roles and work together. Cooperative extension can provide research based information regarding youth development, horticulture, and access to the 4-H program. A municipality can provide land, equipment, and water. Both organizations can recruit volunteers and apply for monetary grants. Together the program is enhanced when cooperation occurs.

- A large project such as this usually requires an employee due to the time commitment. The employee could be an extension coordinator or a youth recreation director.

- There must be dedication from both parties to follow through with the program. If the Tooele City Youth Garden was discontinued after a lackluster start, hundreds of kids would have missed out on the benefits of $4-\mathrm{H}$ gardening. Establishing working clubs and training caring adults is the first step. Moving away from the common area to private parcels, advertising through the $4-\mathrm{H}$ program, and using extension curriculum increased the popularity of the program.

When these resources can be obtained, a pilot program can be launched. The key to this program is allow youth freedom to have their own club and projects. The experiential learning model can be used to help participants complete projects and achieve goals. It is necessary to allow youth ownership and control of the rented parcel areas. This gives incentives for 4-H members to work hard and learn to reap what they have sown. 


\section{Conclusion}

There have been far reaching effects from this program. To date over 800 youth and their families have participated in the program since the partnership with 4-H was formed in 2002 and the demand has continued to grow. Through this cooperative effort the 4-H program in the county has grown and remained popular, and it has provided youth activities to keep them busy in the summer months while kids are not in school.

This project also gives many youth their first hands-on experience in an agricultural setting. The participants have been able to meet other youth in the community and form friendships with others who share similar interests. The program has provided horticulture and plant science education to youth, parents, and 4-H leaders that have taken part.

The program has become such a vital part of the community that even with the economic down-turn, the club has found additional external funding to continue its work.

\section{References}

Lohr, V.I., \& Pearson-Mims, C.H. (2005). Children's active and passive interactions with plants influence their attitudes and actions toward trees and gardening as adults. HortTechnology, 15, 472-476.

Pothukuchi, K. (2004). Hortaliza: A youth "nutrition garden" in southwest Detroit. Children, Youth, and Environments, 14, 124-155.

Robertson, J.G. (1994). Learning Best through Experience. Journal of Extension. Volume 32, Number 2.

Tooele County Profile. (2009). Economic Development Corporation of Utah. http://edcutah.org/files/Tooele County Profile.pdf. Internet Release Date: January 2009.

(C) Copyright of Journal of Youth Development Bridging Research and Practice. Content may not be copied or emailed to multiple sites or posted to a listserv without copyright holder's express written permission. However, users may print, download or email articles for individual use. 